\title{
End of the Supercycle and Growth of Commodity Producers: The Case of Chile
}




\title{
WP/15/242
}

\section{IMF Working Paper}

\section{End of the Supercycle and Growth of Commodity Producers: The Case of Chile}

\author{
by Luc Eyraud
}

IMF Working Papers describe research in progress by the author(s) and are published to elicit comments and to encourage debate. The views expressed in IMF Working Papers are those of the author(s) and do not necessarily represent the views of the IMF, its Executive Board, or IMF management.
I $\mathrm{N}$
N T E R N A T I O N A L
$M O N E T A R Y$
F U N D 


\title{
IMF Working Paper
}

Western Hemisphere Department

\section{End of the Supercycle and Growth of Commodity Producers: \\ The Case of Chile ${ }^{1}$ \\ Prepared by Luc Eyraud}

Authorized for distribution by Roberto Cardarelli

November 2015

IMF Working Papers describe research in progress by the author(s) and are published to elicit comments and to encourage debate. The views expressed in IMF Working Papers are those of the author(s) and do not necessarily represent the views of the IMF, its Executive Board, or IMF management.

\begin{abstract}
This paper estimates the effect of copper prices on Chile's growth at various time horizons. We find that a price decline is likely to have a durable (although not permanent) effect on GDP growth: while the impact is the strongest in the first 3 years after the shock, the transition towards the new lower steady-state GDP level generally takes 5-10 years. From a production function perspective, the GDP growth slowdown is mainly driven by lower capital accumulation.
\end{abstract}

JEL Classification Numbers: F43, O47, O54, Q02, Q30

Keywords: Chile, Commodities, Copper, Growth

Author’s E-Mail Address: LEyraud@imf.org

\footnotetext{
${ }^{1}$ This paper benefited from the comments of Roberto Cardarelli, Benjamin Carton, Jorge Roldos, Ricardo Vicuna, and the participants of the May 5, 2015 seminar at the IMF. Ehab Tawfik provided outstanding research assistance. Alexandra Martinez provided editorial help.
} 
Contents

Page

I. Introduction $\underline{4}$

II. Copper Price Outlook: Temporary Or Structural Decline? $\underline{5}$

III. Does The Level Of Commodity Prices Affect Long-Term Growth? $\underline{8}$

IV. Conclusion $\underline{15}$

Figures

1. Quarterly Growth of Copper Price, GDP, and Investment

2. Historical Price of Copper $\underline{4}$

3. Copper Price Supercycle

4. Coherency Between Real Copper Price and Real GDP Growths

5. Real GDP Components Before/After Copper Price Peak

6. Impulse Reponse Function: Log Real GDP

A1. Copper and the Chilean Economy

A2. Macroeconomic Effects of Copper Prices in Chile

Tables

1. Augmented Dickey-Fuller Tests $\underline{25}$

2. Theoretical Impact on GDP of A Decline in Commodity Prices

3. Various VECM Models Relating Real GDP and Copper Prices

A1. Nominal Copper Price Equations

Appendices

I. Spectral Analysis Concepts

II. A Simple Model of Copper Prices

$\underline{20}$

III. Theoretical Effects of Commodity Price Shocks on GDP Growth

Appendix Box

A1. Hotelling's Rule 


\section{INTRODUCTION}

The sharp decline in copper prices since 2011 has exacted a toll on Chile's GDP growth. Copper prices decreased by almost 50 percent between the peak of February 2011 and August 2015 from $\$ 4.5$ per pound to $\$ 2.3$. Given the importance of the copper sector (which represents 10 percent of Chile GDP, originates half of exports, and receives half of FDI inflows as of $2014^{2}$ ), a large macroeconomic effect was inevitable. GDP growth slowed down from an average pace of 5 percent a year over 2004-13 to around 2 percent in 2014 and the first half of 2015..$^{3}$ At the same time, investment collapsed, with gross fixed capital formation contributing negatively to growth since the second half of 2013. Figure 1 shows that the correlation between copper price, GDP, and investment is a long-standing feature of the Chilean economy.

Figure 1. Quarterly Growth of Copper Price, GDP, and Investment

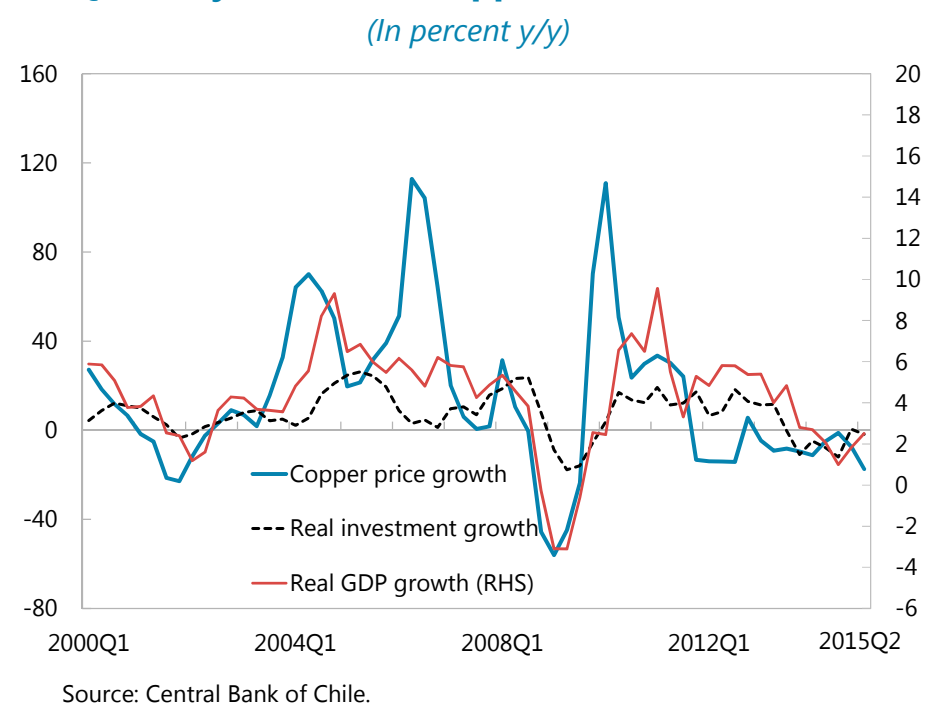

With copper prices unlikely to return to recent peaks in the coming years, the question arises as to whether Chile's long-term GDP growth will be affected. In September 2015 copper future contracts settled at $\$ 2.4-2.5$ per pound, with a stable price profile across delivery dates until 2020. Moreover, the normalization of U.S. interest rates and China's gradual move towards a less metal-intensive growth model pose downside risks to copper prices. Some even argue that commodity prices have entered the downward phase of a supercycle (Erten and Ocampo, 2012; Jacks, 2013; Canuto, 2014). With Chile's growth heavily reliant on capital accumulation in the past two decades (IMF, 2014), lower terms of trade could hamper mining investment and ultimately reduce potential growth in Chile.

\footnotetext{
${ }^{2}$ See Appendix Figures 1 and 2 on the role of copper in the Chilean economy.

${ }^{3}$ The decline in copper prices is not the only force behind the economic slowdown (see IMF $(2014,2015 \mathrm{a})$ for a discussion of the role of domestic and external factors).
} 
Still, there is some uncertainty, both from theoretical and empirical standpoints, about the relationship between commodity prices and long-run GDP growth. Theoretically, a negative commodity price shock may have either no effect on long-term growth (if it is a pure demand shock), a positive effect (if it triggers a reallocation of resources towards more productive sectors), or a negative effect (if lower investment has negative externalities on the economy). At the empirical level, many papers question the traditional view that a smaller commodity exporting sector is beneficial to long-term growth by showing that it depends on the quality of institutions, the country's openness to trade, and the level of human capital (De Gregorio, 2009).

This paper attempts to quantify the effect of lower copper prices on Chile's growth at various time horizons. Section II discusses the copper outlook and argues that copper prices are unlikely to return to historical highs in the near future. Section III provides theoretical and empirical evidence supporting the view that long-term GDP growth will not be affected, but the transition towards a lower GDP level can take up to a decade. Section IV concludes.

\section{Copper Price Outlook: Temporary Or Structural Decline?}

This section evaluates the claim that copper prices are in the downward phase of a super cycle. The macroeconomic effect of commodity price shocks crucially depends on their size and persistence. The first step of this analysis is thus to come up with a working assumption regarding the future behavior of copper prices. To this end, the section discusses some statistical properties of the price series with a long-term perspective, and presents the results of a simple regression model of copper prices.

Figure 2. Historical Price of Copper

(In U.S. cents per pound)

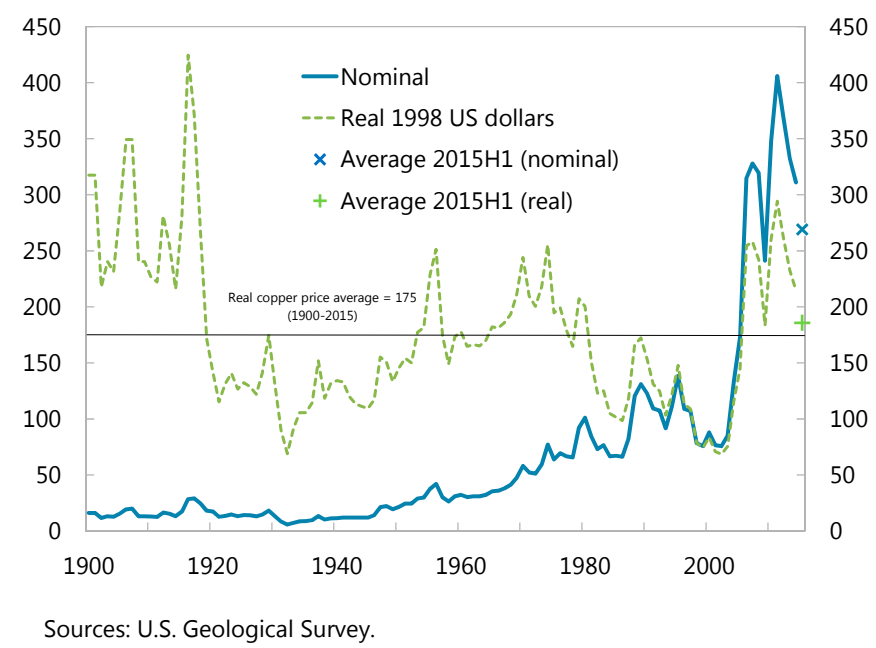


In the long-term, real copper prices tend to revert from historical highs to their mean. ${ }^{4}$ While nominal copper prices show a clear upward trend, real copper prices (deflated by the US CPI) seem to present a cyclical pattern with a tendency to return to long-run equilibrium (Figure 2). Table 1 presents some simple Dickey-Fuller stationarity stationarity tests on real prices showing that about 15 percent of the gap is closed every year on average - a result similar to Frankel (2011). ${ }^{5}$ Real copper prices would need to depreciate by another 20 percent (resp. 5 percent) from their average 2014 (resp. H1 2015) level to reach their long-term mean. ${ }^{6}$

Table 1. Augmented Dickey-Fuller Tests

Real copper price

\begin{tabular}{lcc}
\hline \hline & Coefficient & t-Statistic \\
copper price real(-1) & -0.14 & -2.70 \\
d(copper price real(-1)) & 0.24 & 2.70 \\
d(copper price real(-2)) & -0.21 & -2.26 \\
constant & 524.24 & 2.53 \\
\hline Augmented Dickey-Fuller test statistic & -2.70 \\
Probability & & 0.08 \\
\hline \hline & & \\
Log of real copper price & Coefficient & t-Statistic \\
\hline & -0.15 & -3.47 \\
log copper price real(-1) & 0.25 & 2.71 \\
d(log copper price real(-1)) & 1.24 & 3.46 \\
constant & & -3.47 \\
\hline Augmented Dickey-Fuller test statistic & 0.01 \\
\hline Probability & &
\end{tabular}

Another feature of real copper price fluctuations is that they combine several cycles of various durations. Two separate exercises are conducted to identify these cycles. First, we use a tool called spectral analysis which decomposes the price series into components with different periodicities ${ }^{7}$ (Appendix 1). Applied from 1900, the spectral analysis isolates three

\footnotetext{
${ }^{4}$ This section uses 1900 - 2014 data from the US Geological Survey available at http://minerals.usgs.gov/minerals/pubs/historical-statistics/.

${ }^{5}$ The coefficient of the lagged dependent variable $(-0.15)$ provides an estimate of the adjustment speed.

${ }^{6}$ Consulting firms forecast higher long-term real copper prices than the historical mean based on the assumption that marginal production costs will increase due to lower ore grades and the need to exploit deeper deposits. This break in the historical pattern is implicitly predicated on the absence of major technological innovations that would modify the marginal cost curve.

${ }^{7}$ In this paper, the terms "periodicity," "period," and "time horizon" are used as synonyms. A long-term (resp. short-term) cycle is a cycle with a long (resp. short) period or periodicity, measured as its peak-to-peak duration.
} 
main cycles for real copper prices: a "supercycle" of 50-60 years, a medium cycle of 20 years, and a short cycle of about 10 years. ${ }^{8}$ Second, a band-pass filter is applied to real copper prices to extract the longest cycle (Figure 3). ${ }^{9}$ The filtered series shows three long episodes of copper price booms (followed by long periods of moderation), which can be intuitively associated with global demand booms, such as the industrialization of the late 19th century, the reconstruction period after World War II, and the urbanization of the Chinese economy since the 1990s. Based on this analysis, the supercycle appears to have plateaued in 2012-14.

Figure 3. Copper Price Supercycle

\section{(In U.S. dollars per ton)}

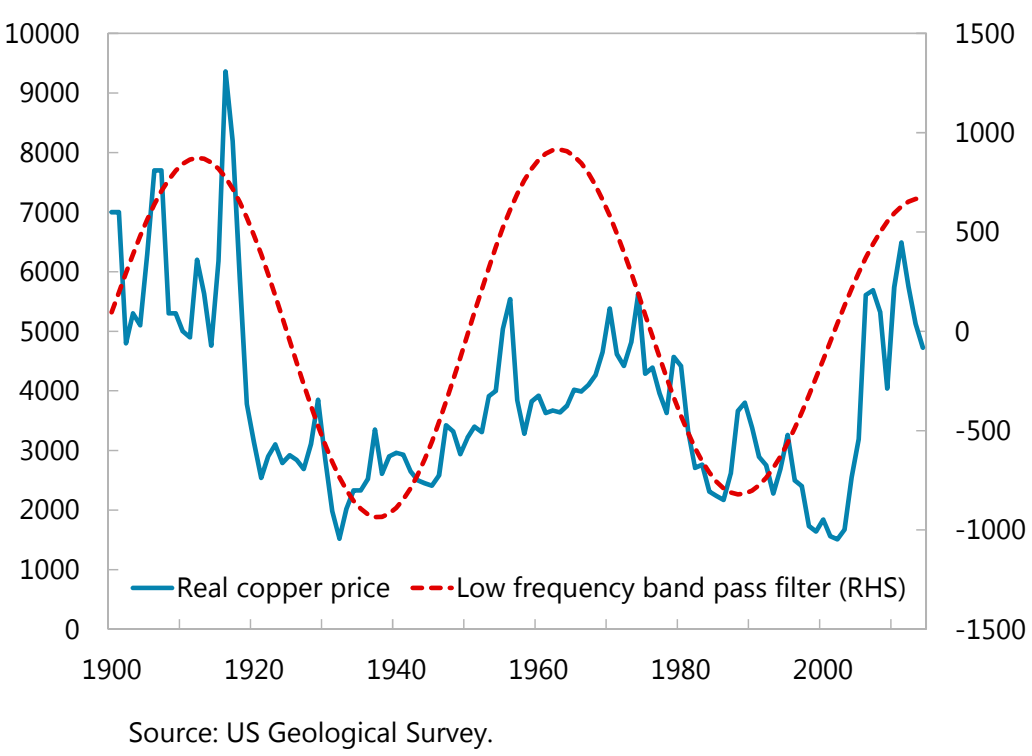

Looking ahead, the expected growth slowdown in China and the normalization of global interest rates could exert further pressure on copper prices. Appendix 2 presents a simple econometric model, where copper prices are a function of a short set of determinants, including China GDP growth, the U.S. real effective exchange rate, the U.S. long interest rates, and market price expectations (as measured by future contracts). Using medium-term forecasts contained in the July 2015 WEO, the equation predicts a 10-15 percent decline in

\footnotetext{
${ }^{8}$ Technically, the periodicity of these three cycles corresponds to peaks in an indicator called "periodogram" (at the frequencies $0.1,0.33$, and 0.49 ). In the case of the shortest cycle, a visual analysis of the data confirms a succession of 10-year patterns, peaking in 1906, 1916, 1927, 1938, 1955, 1972, 1978, 1989, 1995, and 2008.

${ }^{9}$ The asymmetric Chistiano-Fitzgerald filter is applied to the 40-60 year window.
} 
nominal copper prices relative to 2014, as the expected depreciation of the U.S. REER should not be sufficient to offset the combined negative effect from lower China GDP growth and higher U.S. rates.

\section{Does The Level of Commodity Prices Affect Long-Term Growth?}

This section provides theoretical and empirical evidence showing that commodity price shocks are likely to have only a temporary effect on GDP growth. After reviewing the main arguments of the theoretical debate, we use three different methods to estimate the impact of lower commodity prices on GDP growth at different time horizons, as well as the speed of convergence towards equilibrium.

\section{A. A Theoretical Perspective}

The economic theory typically highlights four main transmission channels from a decline in commodity prices to the GDP growth of producers:

- Return: A commodity price decline affects the return of investment and extraction, whether it is measured as the marginal productivity of capital (standard neoclassical investment model), profitability (Tobin's Q model), or capital gains on commodity prices (Hotelling model). This channel would typically predict a temporary negative effect on GDP growth.

- Savings: Lower commodity prices erode the income generated by the commodity sector, reducing savings and investment other factors being equal. Depending on the growth model, lower savings may have a temporary or a permanent negative effect on GDP growth.

- Resource reallocation: Capital and labor move from the commodity sector to sectors producing other tradable and non-tradable goods. In models with learning by doing in the non-commodity tradable sector (that is, productivity grows with the size of the sector), the resource shift has a persistent positive effect on growth.

- Governance: Some models assume that a contraction of the commodity sector could foster entrepreneurship and reduce rent-seeking behaviors, generating a permanent positive growth payoff.

Table 2 summarizes the results of several models highlighting these channels. ${ }^{10}$ Although there is no consensus in the literature, most models suggest that a permanent decline in commodity prices has a permanent effect on the level of GDP, and a temporary effect on its growth rate. Because the capital stock adjusts gradually to reflect the change in the marginal value of production, GDP growth is affected during the transition to the new steady-state. A

\footnotetext{
${ }^{10}$ See Appendix 3 for a more thorough review of the models.
} 
relevant empirical question is thus how GDP growth behaves on the path towards a lower output level. This is the main focus on the following sections.

Table 2. Theoretical Impact on GDP of A Decline in Commodity Prices

\begin{tabular}{l|c|c|c|c}
\hline & \multicolumn{2}{|c|}{ Short-term } & \multicolumn{2}{c}{ Long-term } \\
\cline { 2 - 5 } & GDP level & GDP growth & GDP level & GDP growth \\
\hline Neoclassical investment model & - & - & - & $\varnothing$ \\
\hline Tobin's Q investment model & - & - & - & $\varnothing$ \\
\hline Commodity extraction model & $-/+$ & $-/+$ & $\varnothing$ & $\varnothing$ \\
\hline Salter-Swan model & $\varnothing$ & $\varnothing$ & $\varnothing$ & $\varnothing$ \\
\hline Salter-Swan with learning by doing & + & + & + & + \\
\hline Institutional model & + & + & + & + \\
\hline Solow growth model & - & - & - & $\varnothing$ \\
\hline Endogenous (AK) growth model & - & - & - & - \\
\hline Price volatility model & $\varnothing$ & $\varnothing$ & $\varnothing$ & $\varnothing$ \\
\hline
\end{tabular}

Note: -/+ denotes a negative/positive effect. $\varnothing$ denotes no effect.

\section{B. Statistical Approach}

To test the assumption that lower commodity prices affect GDP growth only in the shortterm, we first look at the statistical properties of the relationship between GDP and copper prices in Chile. Specifically, we use a co-spectral analysis, which provides insights on the comovement between two time series at various time horizons (Appendix 1). The technique is applied to the log differences of real copper prices and Chile real GDP over the period 1900-2014. We also use an alternative specification with de-trended GDP and the logarithm of real copper prices, both series being stationary.

The co-spectral analysis suggests that the correlation between copper prices and GDP weakens in the long run. To measure the strength of the relationship between the growth of copper prices and Chile's GDP growth at different time horizons, we use an indicator called "coherency." This indicator shows that the co-movement of the two series is stronger for 
their short-term fluctuations than for their long cycles (Figure 4). ${ }^{11}$ Another interesting result of the cospectral analysis is that copper prices lead output fluctuations. This is evidenced by the "phase angle," which measures the lead-lag relationship between the two series at different periodicities. In our sample, the phase angle is almost always positive, which means that the copper price series leads real GDP regardless of the time horizon.

Figure 4. Coherency between Real Copper Price Growth and Real GDP Growth

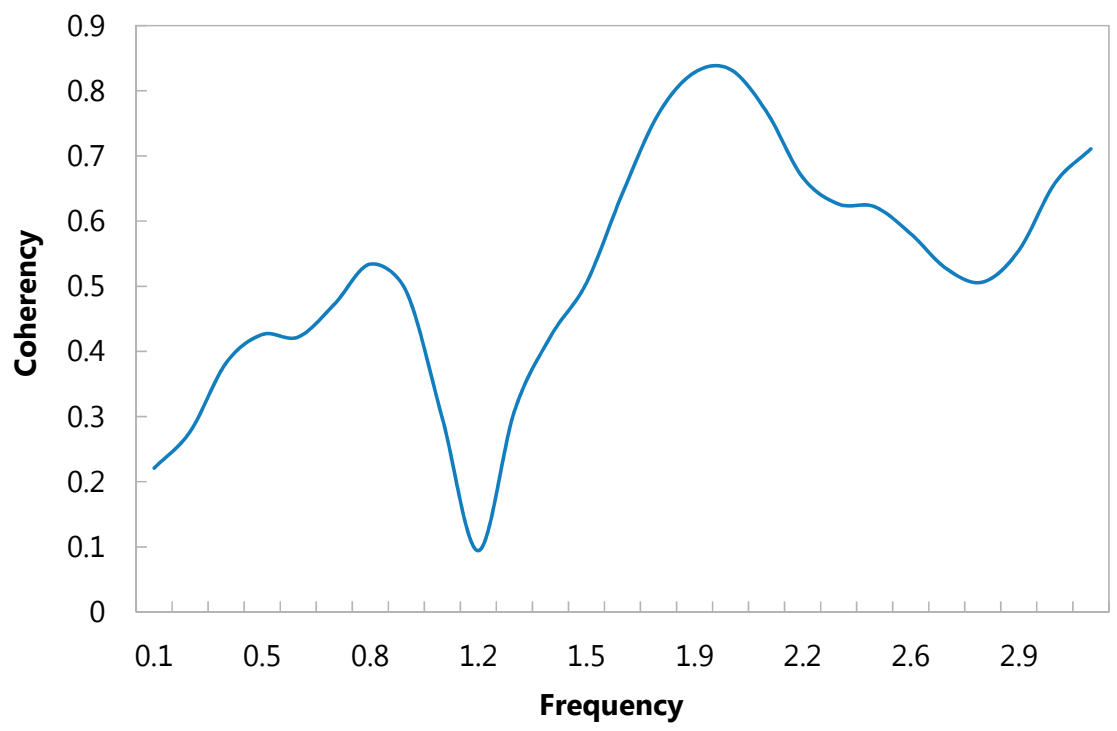

Source: US Geological Survey and Staff estimate.

\section{Event Analysis}

To assess the short-term macroeconomic impact of a decline in copper prices, we conduct an event analysis of the copper price and business cycles in Chile. Extending Spilimbergo (1999), we identify six real copper price cycles since the mid-1980s and analyze the behavior of real GDP before and after the copper price peaks. ${ }^{12}$ This analysis is only relevant to assess the short-term effect of a copper price shock: after a few quarters, GDP is affected by a multitude of other factors, which are likely to conceal the effect of the initial shock.

The event analysis confirms that the business and copper price cycles are tightly linked in Chile. In the sample, real copper prices decline, on average, by 25 percent in the year following the peak. The two series follow broadly the same pattern: in general, GDP growth

\footnotetext{
${ }^{11}$ Strictly speaking, this finding does not prove that copper prices do not affect long-term growth, but it is a supporting argument. If long-term growth was impacted, it is very likely that the long cycles of copper price growth and output growth would co-move.

12 The analysis is constrained by the availability of quarterly data, which start in 1986 . The peaks in real copper prices are 1989Q1, 1995Q3, 1997Q2, 2006Q3, 2008Q2, and 2011Q1.
} 
peaks one or two quarters after copper prices, then decelerates by about 1 percentage point on a quarterly basis in the following two years. ${ }^{13}$ The GDP deceleration occurs mainly because investment decelerates strongly after the peak, dragging down imports (one fourth of which are capital goods, on average), whereas consumption and exports do no show a clear pattern (Figure 5).

Figure 5. Real GDP Components Before/After Copper Price Peak

(In percent $y / y$; median over 6 cycles since mid-1980s)

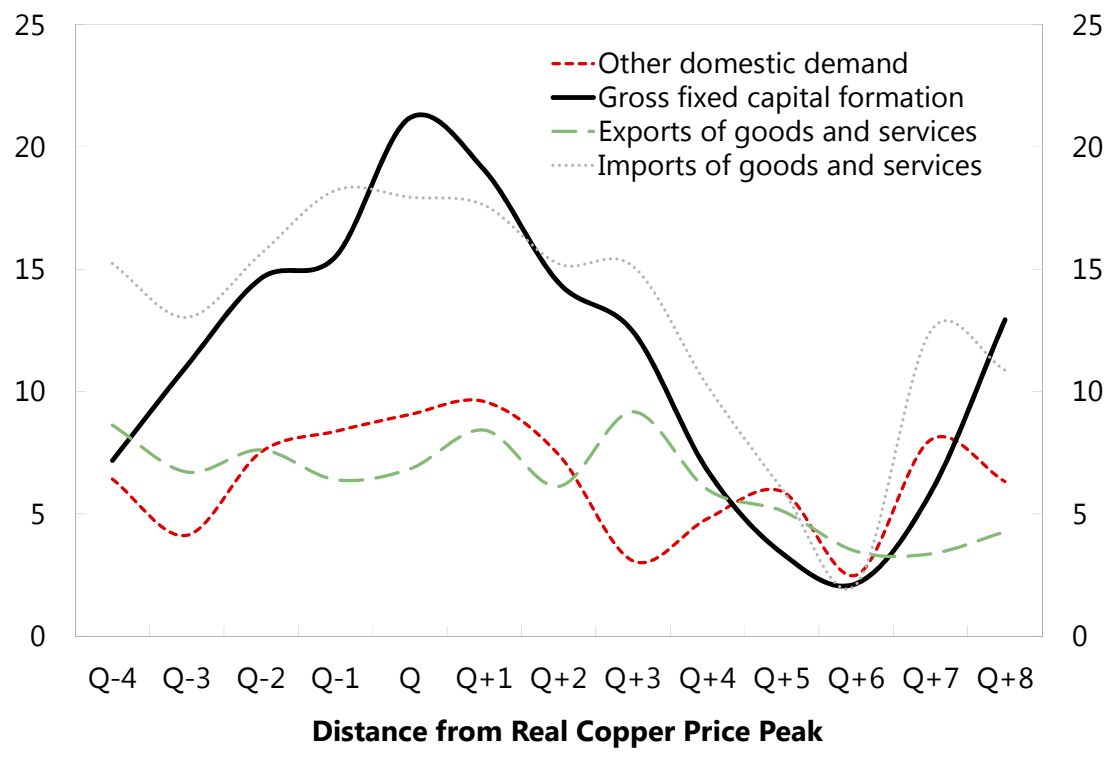

\section{Econometric Analysis}

The behavior of GDP after a commodity price shock can also be analyzed within a Vector Error Correction Model (VECM). Assuming that copper prices have transitory effects on GDP growth and a permanent effect on the GDP level, the VECM constitutes a natural instrument to estimate transitional dynamics when a shock moves variables away from

\footnotetext{
${ }^{13}$ We compute the difference between (i) the average year-on-year quarterly growth rate over the 4 quarters preceding the peak and (ii) the average growth rate during the 8 quarters following it. Interestingly, the implied elasticity $(0.04=1 / 25)$ is very close to the short-term effect on GDP growth estimated by the econometric models (VECM) presented in the next section.
} 
equilibrium. ${ }^{14}$ Constrained by data availability, our quarterly sample starts in 1990. Most of the specifications have a four-lag structure determined by standard lag length criteria.

Table 3. Various VECM Models Relating Real GDP and Copper Prices

\begin{tabular}{|c|c|c|c|c|c|c|c|c|c|}
\hline & Model 1 & Model 2 & Model 3 & Model 4 & Model 5 & Model 6 & Model 7 & Model $8^{1 /}$ & Model $9^{1 /}$ \\
\hline Period & $\begin{array}{l}1990- \\
2014\end{array}$ & $\begin{array}{l}1990- \\
2014\end{array}$ & $\begin{array}{l}1990- \\
2014\end{array}$ & $\begin{array}{l}1990- \\
2014\end{array}$ & $\begin{array}{l}1990- \\
2014\end{array}$ & $\begin{array}{l}2003- \\
2014\end{array}$ & $\begin{array}{l}1990- \\
2014\end{array}$ & $1990-2014$ & $1960-2014$ \\
\hline \multicolumn{10}{|l|}{ Cointegrating Equation } \\
\hline $\log ($ real GDP)(-1) & 1.00 & 1.00 & 1.00 & & 1.00 & 1.00 & & 1.00 & 1.00 \\
\hline \multirow[t]{2}{*}{ Log (copper price)(-1) } & -0.37 & & -0.37 & -0.30 & -0.43 & -0.33 & & -0.33 & \\
\hline & {$[-5.14]$} & & {$[-5.24]$} & {$[-5.12]$} & {$[-4.75]$} & [-17.39] & & {$[-6.54]$} & \\
\hline Log (national savings rate)(- -1$)$ & $\begin{array}{c}1.09 \\
{[2.68]}\end{array}$ & $\begin{array}{c}1.33 \\
{[2.62]}\end{array}$ & $\begin{array}{c}0.96 \\
{[2.28]}\end{array}$ & $\begin{array}{c}0.89 \\
{[2.70]}\end{array}$ & $\begin{array}{c}0.92 \\
{[1.84]}\end{array}$ & $\begin{array}{c}0.69 \\
{[7.93]}\end{array}$ & $\begin{array}{c}0.77 \\
{[4.27]}\end{array}$ & $\begin{array}{c}1.12 \\
{[3.80]}\end{array}$ & \\
\hline Constant & -15.06 & -17.09 & -15.25 & 1.19 & -15.25 & -15.77 & -7.89 & 0.15 & -15.67 \\
\hline Log (real copper price)(-1) & & $\begin{array}{c}-0.46 \\
{[-4.10]}\end{array}$ & & & & & & & $\begin{array}{c}-0.42 \\
{[-2.86]}\end{array}$ \\
\hline Log (real GDP per capita)(-1) & & & & 1.00 & & & & & \\
\hline Log (non-mining GDP)(-1) & & & & & & & 1.00 & & \\
\hline Log (mining GDP)(-1) & & & & & & & $\begin{array}{c}-0.50 \\
{[-6.14]}\end{array}$ & & \\
\hline Log (openness ratio) ${ }^{2 /}$ & & & & & & & & & $\begin{array}{c}-1.52 \\
{[-6.02]}\end{array}$ \\
\hline Log (investment ratio) ${ }^{2 /}$ & & & & & & & & & $\begin{array}{c}-1.29 \\
{[-2.81]}\end{array}$ \\
\hline \multicolumn{10}{|l|}{ Short-Term Dynamics } \\
\hline Number of lags & 4 & 4 & 4 & 4 & 2 & 6 & 4 & 1 & 1 \\
\hline Alpha of dlog(real GDP) equation & -0.03 & -0.02 & -0.03 & -0.04 & -0.03 & -0.07 & -0.06 & -0.09 & -0.05 \\
\hline \multicolumn{10}{|l|}{ Exogenous Variables } \\
\hline dummy 2008Q4, Q1, Q3 & $x$ & $x$ & $x$ & $x$ & $x$ & $x$ & $x$ & & \\
\hline $\begin{array}{l}\text { dlog(China GDP), } d(V I X), d(f e d \\
\text { fund rate) }\end{array}$ & & & $x$ & & & & & & \\
\hline
\end{tabular}

We tested the existence of long-term relationships between real GDP, nominal copper prices and the following variables: the openness ratio, the investment rate, the national savings rate, ${ }^{15}$ population growth, the price level, inflation, and the REER. Our baseline model includes the log of Chile real GDP, the log of nominal copper prices, and the log of the

\footnotetext{
${ }^{14}$ The method is similar to Collier and Goderis (2012), who estimate an annual panel VECM over 1963-2008 in 120 countries using aggregate commodity price indices.

${ }^{15}$ The savings rate is calculated as the difference between nominal GDP and "other domestic demand," in percent of GDP.
} 
national savings rate (Table 3 , model 1$).{ }^{16}$ Over the period considered, a cointegration relationship exists between these variables. ${ }^{17}$ The levels of GDP and copper prices are positively related in the long-run, suggesting that significant Dutch disease effects are prevented in Chile by the sound macroeconomic policy framework, including a structural fiscal rule that forces the government to save extra copper revenues above long-term reference prices, the inflation targeting regime, and a floating exchange rate regime with interventions limited to mitigating temporary misaligments. The sign of the savings rate could signal a consumption smoothing behavior, with national savings increasing with copper prices — partly because of the fiscal rule in place since 2000 .

After a copper price shock, the transition towards the new steady state takes several years. Depending on the model, the length of convergence spans over 5-10 years. ${ }^{18}$ Following a 20 percent nominal price shock, GDP stabilizes at a level which is between 2 and 4 percent below baseline in the long run. ${ }^{19}$ This effect is similar in magnitude and duration to that estimated by Fornero and others (2015) in a SVAR with persistent shocks. Results are robust to alternative specifications, including (i) a shorter period (e.g., the commodity boom of 2003-14), (ii) using alternative variable definitions (real copper prices, GDP per capita), (iii) fewer lags, (iv) annual data, ${ }^{20}$ and (v) with an exogenous block including China GDP growth, the change in the Fed funds rate and the change in the VIX index (all results are reported in Table 3, models 2-9).

\footnotetext{
${ }^{16}$ The models passes a number of standard tests, including length lag tests for the unrestricted VAR, integration of individual variables, and Johansen cointegration tests.

${ }^{17}$ Nominal and real copper prices have followed a similar evolution since the 1990s, and both are found to be integrated over the period, which is the reason why they can be used interchangeably in the equation (but the previous section showed that over a longer period, the log of real copper prices is likely to be stationary). Model 1 (resp. 2) corresponds to the specification with nominal (resp. real) copper prices.

${ }^{18}$ Simulations use the following Cholesky ordering for the baseline model: copper prices, savings rate, and GDP.

${ }^{19} 20$ percent corresponds approximately to the estimated size of the "permanent" nominal shock, proxied by the decline between the average nominal copper price during the boom years (2006-13) and the average price projected over 2014-20 in the October 2015 WEO. In addition, 20 percent happens also to be the decline in real copper prices between H1 2015 and 2020 in the WEO.

${ }^{20}$ Annual regressions are conducted over 1990-2014 and 1960-2014. Over the longer period, we find a cointegration relationship between Chile real GDP (in log), real copper prices (in log), the openness ratio (exports plus imports divided by GDP, in log), and the investment ratio (gross fixed capital formation in percent of GDP, in log).
} 
The effect of the price shock on GDP growth is frontloaded (Figure 6). In all models, GDP does not decline linearly over 5-10 years. Most of the growth decline is concentrated in the first three years. At the WEO projection horizon (5 years), GDP growth is found to be 0.10.2 percentage point below baseline for a 20 percent price shock. The precise point estimate is very sensitive to the specification. For instance, annual models generally produce a faster adjustment, and consequently, a smaller growth deceleration in the fifth year, perhaps because of their smaller number of lags.

Figure 6. Impulse Response Function: Log Real GDP

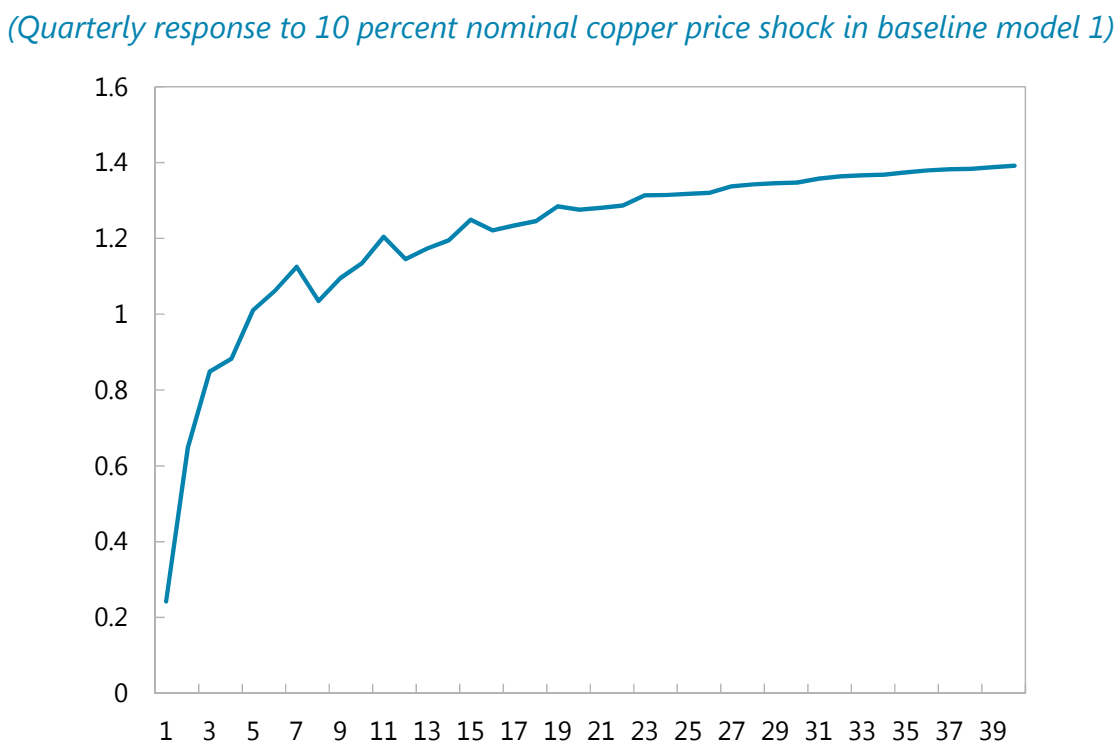

Taking a production function approach to growth, an important question is whether the negative effect on GDP growth is driven by lower capital accumulation or by other factors. To assess the effect of a copper price shock on investment, we estimate annual VECMs since 1960 (longest sample available). ${ }^{21}$ Over this period, we find alternative cointegration relationships between nominal copper price, real GDP, the capital stock, and either the openness ratio or the REER and a linear trend (all variables in logarithm). We also estimate another model with two cointegration relationships, and impose (and test) restrictions on the long-term and short-term coefficients to identify the equations. ${ }^{22}$ Short-term dynamics include dummies for the 1975 and 1982 crises. Overall, these models show that a 20 percent fall in nominal copper prices reduces capital accumulation by about $0.1-0.3$ percentage points (relative to the baseline) after five years.

\footnotetext{
${ }^{21}$ The capital stock variable is only available at the annual frequency. The models' results are not reported here but available from the author upon request.

${ }^{22}$ One cointegration relationship relates GDP per capita and the capital stock; the other one relates GDP per capita, openness ratio and real copper price.
} 
The negative effect on capital accumulation could potentially be (partly) offset by a positive response of total factor productivity (TFP) growth if lower copper prices were to trigger a reallocation of resources from mining towards higher-productivity sectors. To test whether the data confirm this hypothesis, we re-estimate the quarterly VECM (over 1990-2014 with the national savings rate and nominal copper prices) but differentiate between mining and non-mining output. We do not find evidence of reallocation between the two sectors after the price shock. The fall in mining output is marginal, suggesting that the supply elasticity of copper output is quite small. Most of the output decline occurs in fact in the non-mining sector, perhaps because of negative wealth effects or because some copper-related production is recorded in other sectors (e.g., infrastructure). As a result, aggregate TFP growth declines after a negative copper price shock. However, using the model's output estimates and assumptions on TFP growths in each sector, we find that the aggregate TFP growth decline is marginal (below 0.05 percentage point) in the medium-run after a 20 percent nominal copper price shock. $^{23}$

\section{Conclusion}

Chile is facing the question of how the copper price boom of the 2000 s and the recent slump have affected its long-term growth. To contribute to this debate, this paper argues on theoretical and empirical grounds that the copper price decline is likely to have a durable (although not permanent) effect on GDP growth. While the impact of lower copper prices is the strongest in the first 3 years after the shock, the transition towards the new lower steadystate GDP level generally takes 5-10 years. From a production function perspective, the reduction in GDP growth is mainly driven by lower capital accumulation in the short and medium term, while the TFP channel seems less important.

Persistent growth effects of low copper prices emphasize the importance of economic diversification. While diversification brings many economic benefits including reduced vulnerability to terms of trade shocks and lower macroeconomic volatility, Chile, like several other countries in Latin America such as Brazil, Mexico and Peru, has experienced a decline in diversification in recent years (IMF, 2015b). In the case of Chile, diversification is all the more important that the copper sector is facing difficult challenges, including rising costs of energy and labor, declining productivity (primarily due to the ageing of existing mines and lower ore grade), and tighter environmental and labor regulations.

\footnotetext{
${ }^{23}$ We assume TFP growth rates of -5 percent a year in the mining sector and +0.5 percent in the non-mining sector - a calibration close to actual 2013 estimates according to CORFO (2014).
} 
A number of structural bottlenecks have contributed to Chile's disappointing productivity performance in the last 15 years and may hinder the reallocation of resources and production away from copper towards new activities:

- Higher quality and more inclusive education. By enhancing the labor force skills, the authorities' education agenda can help workers become more fungible and strengthen the firms' ability to adopt new technologies and organizational innovations.

- Flexible product and labor markets. Product and labor market rigidities also impede resource reallocation. Product market competition remains below average by OECD standards, as reflected in high price-cost margins. Entry and exit regulations for businesses are restrictive in some sectors (Schwellnus, 2010). In the labor market, high minimum wages limit the scope for relative wage adjustment between copper and noncopper sectors, in particular for low-skilled and young workers. ${ }^{24}$

- Support to innovation. At 0.4 percent of GDP, Chile's R\&D spending is the lowest in the OECD (2 percent of GDP on average), particularly in the private sector. The government has put in place a number of initiatives to boost innovation (such as "Start-up Chile", a program that provides seed money to start ups), but there is room to expand and rationalize these programs as well as to strengthen collaboration between firms and universities, or other research institutions (OECD, 2013).

\footnotetext{
${ }^{24}$ Micco and Repetto (2012) describe how labor market regulations impede the reallocation of labor across plants in Chile by reducing the turnover and the capacity of wages to adjust.
} 


\section{Appendix I. Spectral Analysis Concepts}

\section{Spectral analysis}

Stationary time series can be written as a linear combination of orthogonal cyclical (trigonometric) functions, also known as their Fourier representation. The "spectrum" of a time series, which is the central concept of the spectral analysis, is the Fourier representation of the autocovariance function of the series. The spectrum enables to identify the frequency components that make the greatest contribution to the overall variance of the series. The sample counterpart of the theoretical (infinite) spectrum is called the "periodogram." A peak of the periodogram at frequency $\mathrm{f}($ or $\mathrm{w}$ ) denotes a cycle of period $\mathrm{T}=1 / \mathrm{f}$ (or $2 \mathrm{pi} / \mathrm{w}$ ) in the original series. $^{25}$

\section{Co-spectral analysis}

The spectral analysis can be extended to a multivariate case in order to measure the comovement between series. The most commonly indicators are called the "coherence" or "coherency" (which estimates the correlation between the series at a particular frequency), the "phase angle" (measuring the lead-lag between the cycles of the two series at a particular frequency) and the "gain" (which calculates the difference in the cycle amplitude).

\section{Band-pass filters}

A "low (resp. high) pass" filter passes low (resp. high)-frequency signals and blocks high (resp. low)-frequency ones. A "band pass" filter passes signals whose frequency lies in a certain frequency band. An example of such filter is the Christiano-Fitzgerald (CF) filter, which is used to isolate the cyclical component of a time series by specifying a range for its duration. This paper uses the full sample asymmetric form of the CF filter, which is the most general form. The alternative, using a fixed-length filter (such as the Baxter-King filter) would require that we rely on the same number of lead and lag terms for every weighted moving average. This would imply losing observations at the beginning and the end of the sample. The asymmetric filter does not impose this requirement and can be computed until the last data point of the sample.

\footnotetext{
${ }^{25} \mathrm{~T}$ denotes the period, $\mathrm{f}$ the frequency, $\mathrm{w}$ the angular frequency.
} 


\section{Appendix II. A Simple Model of Copper Prices}

This appendix presents the results of quarterly models of nominal copper prices, which are estimated over 1991-2014 with OLS. Table A1 reports the estimates of the baseline model (column 2) and alternative specifications (columns 3-6).

\section{Table A1. Nominal Copper Price Equations}

\begin{tabular}{|c|c|c|c|c|c|}
\hline Dep. Var: & $\mathrm{DL}(\mathrm{COP})$ & $\mathrm{DL}(\mathrm{COP})$ & $\mathrm{DL}(\mathrm{COP})$ & $\mathrm{DL}(\mathrm{COP})$ & $\mathrm{DL}(\mathrm{RCOP})$ \\
\hline DL(real GDP China)(-1) & $\begin{array}{c}5.73 \\
(4.26)^{\star \star}\end{array}$ & $\begin{array}{c}5.59 \\
(4.07)^{\star \star}\end{array}$ & $\begin{array}{c}5.75 \\
(4.31)^{\star \star}\end{array}$ & $\begin{array}{c}2.91 \\
(2.39)^{\star}\end{array}$ & $\begin{array}{c}5.53 \\
(4.13)^{\star \star}\end{array}$ \\
\hline $\begin{array}{c}\mathrm{D}(\text { US10 year bond } \\
\text { yield })(-6)\end{array}$ & $\begin{array}{c}-0.07 \\
(-2.73)^{\star *}\end{array}$ & & $\begin{array}{c}-0.07 \\
(-2.79)^{\star *}\end{array}$ & $\begin{array}{c}-0.06 \\
(-2.10)^{*}\end{array}$ & $\begin{array}{c}-0.07 \\
(-2.73)^{\star \star}\end{array}$ \\
\hline DL(US REER)(-6) & $\begin{array}{c}-0.89 \\
(-2.18)^{*}\end{array}$ & $\begin{array}{c}-0.91 \\
(-2.18)^{\star}\end{array}$ & & $\begin{array}{c}-0.80 \\
(-1.75)\end{array}$ & $\begin{array}{c}-0.84 \\
(-2.07)^{\star}\end{array}$ \\
\hline $\mathrm{D}$ (Net Position Traders) & $\begin{array}{c}0.00 \\
(4.91)^{\star \star}\end{array}$ & $\begin{array}{c}0.00 \\
(4.57)^{\star \star}\end{array}$ & $\begin{array}{c}0.00 \\
(4.92)^{\star *}\end{array}$ & & $\begin{array}{c}0.00 \\
(4.89)^{\star \star}\end{array}$ \\
\hline Dummy Q4 2008 & $\begin{array}{c}-0.60 \\
(-6.81)^{\star \star}\end{array}$ & $\begin{array}{c}-0.63 \\
(-6.91)^{\star *}\end{array}$ & $\begin{array}{c}-0.61 \\
(-6.90)^{\star *}\end{array}$ & $\begin{array}{c}-0.68 \\
(-6.43)^{\star \star}\end{array}$ & $\begin{array}{c}-0.57 \\
(-6.48)^{\star *}\end{array}$ \\
\hline Dummy Q2 & $\begin{array}{c}0.06 \\
(2.56)^{\star}\end{array}$ & $\begin{array}{c}0.06 \\
(2.74)^{\star \star}\end{array}$ & $\begin{array}{c}0.06 \\
(2.55)^{*}\end{array}$ & $\begin{array}{r}0.01 \\
(0.52)\end{array}$ & $\begin{array}{c}0.05 \\
(2.27)^{\star}\end{array}$ \\
\hline Constant & $\begin{array}{c}-0.13 \\
(-3.79)^{\star \star}\end{array}$ & $\begin{array}{c}-0.12 \\
(-3.58)^{\star \star}\end{array}$ & $\begin{array}{c}-0.13 \\
(-3.75)^{\star *}\end{array}$ & $\begin{array}{c}-0.06 \\
(-1.85)\end{array}$ & $\begin{array}{c}-0.13 \\
(-3.79)^{\star *}\end{array}$ \\
\hline $\mathrm{D}($ Fed Fund Rate)(-5) & & $\begin{array}{c}-0.04 \\
(-1.84)\end{array}$ & & & \\
\hline DL(US NEER)(-6) & & & $\begin{array}{c}-0.89 \\
(-2.39)^{*}\end{array}$ & & \\
\hline Observations: & 86 & 86 & 86 & 94 & 86 \\
\hline$R$-squared: & 0.61 & 0.59 & 0.61 & 0.40 & 0.59 \\
\hline F-statistic: & 20.41 & 18.83 & 20.79 & 11.57 & 19.02 \\
\hline
\end{tabular}

Note: COP (resp. RCOP) denotes the nominal (resp. real) copper price; t-statistics in parentheses; ${ }^{* * *(* *, *)}=$ significant at the $1(5,10)$ percent level.

In the baseline model, copper prices (in log difference) are found to be affected by (i) China real GDP (in log difference); (ii) the real effective exchange rate of the dollar (in log); (iii) an indicator of market expectations (net open position of non-commercial traders in copper futures, in log); (iv) the US real fed fund rate (in log); and (v) some time dummies. This 
model explains about 60 percent of the volatility of copper prices over the period. All estimated coefficients are consistent with priors. Copper prices are positively affected by China's growth and the position of non-commercial traders, ${ }^{26}$ and negatively affected by global interest rates ${ }^{27}$ and the U.S. dollar. ${ }^{28}$ The beta coefficients (standardized by the relative standard deviation of each regressor) show that market expectations and China's growth are the main drivers of copper prices. Growth in other regions (Japan, Europe, U.S.) were not found to impact copper prices in a consistent manner.

The model is robust to alternative specifications using real copper prices, the U.S. fed fund rate, real bond yields, and the nominal effective exchange rate of the dollar. An equation excluding the net position of traders is also reported, as this variable is correlated with China's growth and impairs the stability of the coefficients.

\footnotetext{
${ }^{26}$ If large institutional investors (not involved directly in production or distribution of commodities) increase their long positions, it means that they have a bullish bias on the market and expect prices to increase.

${ }^{27}$ If the real interest rate is high, producers are encouraged to extract copper now, sell it, and invest the proceeds in bonds. The result is a fall in demand or rise in supply, which drives down the spot price of copper.

${ }^{28}$ The negative effect of the dollar on commodity prices can be explained by two factors: (i) a "demand effect:" as the price of commodities is set in dollars, foreign countries have to buy commodities at a higher price (in domestic currency), and therefore the demand for commodities declines, which reduces their price; and (ii) a "portfolio reallocation effect:" when the dollar goes up, investors move from the commodity to the currency market.
} 


\section{Appendix III. Theoretical Effects of Commodity Price Shocks on GDP Growth}

This appendix discusses the effects of a permanent exogenous commodity price shock on the GDP of commodity producers. The analysis is conducted in models where commodities are a produced good rather than a production factor.

\section{Static neoclassical investment model}

A permanent exogenous decline in the price of output decreases the marginal productivity of capital (in nominal terms) and hence the firm's demand of capital until the identity between user cost of capital and marginal capital productivity is restored at a higher productivity level. With a Cobb-Douglas function, it is easy to show that the demand for capital depends positively on the output price. In the absence of adjustment costs, the effect is instantaneous. Thus, the model predicts an instantaneous negative effect on GDP growth and a permanent negative effect on the GDP level. Intuitively, at lower copper prices, some projects are not going to be profitable and production will be permanently scaled down with a one-off effect on growth.

\section{Tobin's $Q$ investment model with adjustment costs}

In a Tobin's Q model, investment decisions are forward-looking and depend on the gap between the marginal cost of capital and the marginal value (in terms of future profits) of an additional unit of capital - this value depends on future output prices.

The results of the previous model remain valid: negative price shocks have a temporary negative effect on GDP growth and a permanent negative effect on the GDP level. In addition, the standard Tobin's Q model generally incorporates capital adjustment costs, so that the deceleration of the capital stock is gradual rather than instantaneous.

An important implication of the model is that the effect of a price decline depends on the persistence of the shock. Temporary shocks affect only marginally the sum of future profits, while permanent shocks have a stronger effect on the Q. Therefore, the short-term effect on investment and GDP growth is stronger for permanent shocks.

\section{Commodity extraction model}

In this model, the production/extraction decision today is driven by the expected future rate of increase in commodity prices, not by their current level (Box A1). The short-term effect of the price shock will thus depend on how it impacts price expectations:

- If the negative shock is temporary and prices are expected to recover, the expected growth rate of prices may temporarily exceed the interest rate. Producers will have incentives to postpone production until prices bounce back. GDP growth will 
immediately decline. Compared to previous investment models, production declines because of the expected capital gain, not because investment is not profitable at current prices.

- If the negative shock is believed to be permanent and copper prices do not recover to the pre-shock level (but resume growing at the same rate as in the baseline following the shock), short-term GDP growth will be unaffected. ${ }^{29}$

Regardless of the persistence of the shock, there is no effect on long-term growth. The reason is that production growth depends on the gap between the expected price increase and interest rate; there is no reason to assume that this gap is affected by the initial shock. In addition, output growth in the long-term would most likely be zero, as the stock of commodity is eventually depleted.

\section{Box A1. Hotelling's Rule}

The Hotelling's rule states that non-renewable resources should grow at a pace equal to the interest rate. It may be derived from a social welfare maximization program (Van der Ploeg, 2011). It can also be understood intuitively from a simple arbitrage condition in the commodity market (Frankel 1986, 2011). The decision whether to leave deposits in the ground (and sell them later) versus to extract and sell them at today's price is governed by an arbitrage condition between the interest rate and expected future rate of increase in commodity price. Indeed, one should be indifferent between keeping the resources underground (in which case the return is the capital gain on reserves) and extracting and selling them to get a market return on the proceeds. If producers expect prices to grow at a rate below the interest rate, they will extract all the commodity now, sell it, and invest the proceeds in financial securities. Then, the commodity price will collapse until the expected price growth matches the interest rate. On the opposite, if commodity prices increase faster than the interest rate, producers are better off not bringing the commodity out of the ground, which increases the price of commodities today (due to the supply shortage) and reduces expected capital gains.

In the simplest version of the model, there is perfect substitutability between the financial asset and natural resource, so the discrete decision of the producer is basically to extract or not all resources today. In an open economy where interest rates and copper prices are set exogenously, a gap between these variables can persist. The arbitrage condition becomes: expected rate of increase equals the interest rate minus a "convenience yield" which includes extraction costs (growing with the level of production). If copper prices grow at a rate below the interest rate, producers extract copper until growing extraction costs have restored the parity. In this case, not all resources are extracted.

\footnotetext{
${ }^{29}$ Another possible scenario is that prices decline and stay permanently low (instead of growing at the same pace as in the baseline). In this case, producers will have an incentive to extract and sell all commodities immediately, resulting in a short-term boost of production growth.
} 


\section{Salter-Swan model}

The Salter Swan model, used to describe Dutch disease effects, is an appealing framework to understand the effects of a negative commodity price shock, which is theoretically equivalent to a decline in the stock of natural resources.

A natural resource shortfall results in a reallocation of capital and labor from the non-tradable sector towards the non-commodity tradable sector. In the simplest version of the model, the shift affects neither the aggregate production nor its growth rate; it simply induces a change in the production structure (Van der Ploeg, 2011). Interestingly, even if the non-commodity tradable sector has higher productivity, the resource shift does not increase real aggregate output, because prices are also lower in the non-commodity tradable sector, which implies that its weight in total production is also lower (assuming that output is aggregated with price-based fixed weights, e.g., in a Laspeyres index).

\section{Salter-Swan model with learning by doing}

To generate a long-term growth effect, additional assumptions are necessary (Van der Ploeg, 2011). For instance, the capital and labor reallocation has a permanent growth effect if the non-commodity tradable sector benefits most from learning by doing and other positive externalities - meaning that productivity increases with the size of production or employment in this sector. In this case, a permanent negative commodity price shock boosts GDP growth in the long run.

\section{Institutional models}

Some models explain the poor long-term performance of commodity exporters by weaker institutions and governance rather than Dutch disease. Natural resources may foster corruption, conflicts, wastage, and rent seeking behaviors. Conversely, a reduction in the size of the commodity sector could be beneficial. In these models, the effect of a negative shock on GDP growth and level is positive and permanent.

\section{Solow growth model}

Growth models can incorporate commodity prices in two alternative ways, as an output or as an additional factor of production. In the following, we consider the first case, which is the most relevant to Chile..$^{30}$ The Solow model assumes that the economy produces and consumes a single good. Incorporating a relative price between capital/consumption and the produced

\footnotetext{
${ }^{30}$ In models with exhaustible resources as production factor, production and capital growth is generally negative in the steady state (with output and capital stock converging towards zero), because of the scarcity of the commodity. A change in the stock of resources lifts (up or down) the path but does not affect the steady state (Van der Ploeg, 2011). This result is also valid in a simple endogenous AK model (Aghion and Howitt, 2009).
} 
good marginally modifies the formulas. In the steady state, the stock of capital depends positively on the price of output, but the long-term growth rate does not depend on prices (it depends only on technological progress). Therefore, a commodity price decline is accompanied by a temporary negative effect on GDP growth and a permanent negative effect on the GDP level.

During the convergence towards the new (lower) steady state, growth will be slower than in the baseline. Indeed, a decline in the relative price of output is equivalent to a decline in the savings rate (as lower savings are generated for a given level of real income). ${ }^{31}$ As less saving and investment are generated at each period, the growth rate is (temporarily) slower during the transition.

\section{AK growth model}

In an endogenous growth model (such as the model of learning by doing of Romer (1986) where technical progress is related to the overall stock of capital in the economy), a decline in the price of output would generate less savings and less investment, with a permanent negative effect on GDP growth, because the stock of capital has positive externalities at the macroeconomic level. Thus, the negative effect on GDP growth and level is permanent.

\section{Models focusing on commodity price volatility}

Some argue that the adverse growth effect of natural resources results mainly from the volatility of commodity prices, and the related impact on investment and consumption. In particular, there is some evidence that real exchange rate volatility (either due to the volatility of the commodity or to a Dutch disease effect) may hurt investment. This volatility channel could potentially be more important than direct effects. In this case, a decline in the price level, not accompanied by higher volatility, could have no effect on GDP growth and GDP level.

\footnotetext{
${ }^{31} \mathrm{sPY}=\mathrm{s}^{\prime} \mathrm{Y}$ with s'=sP.
} 
Figure A1. Copper and the Chilean Economy

Copper production represents 10 percent of real GDP.

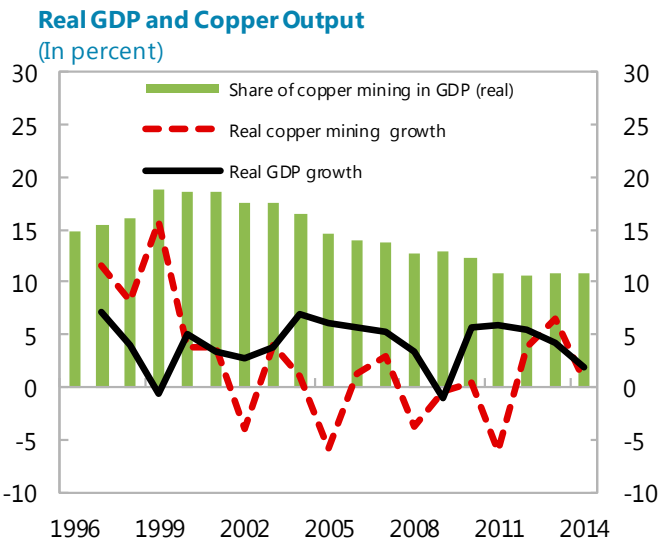

...while production in volume has plateaued.

Copper Production in Chile (In billions of tons)

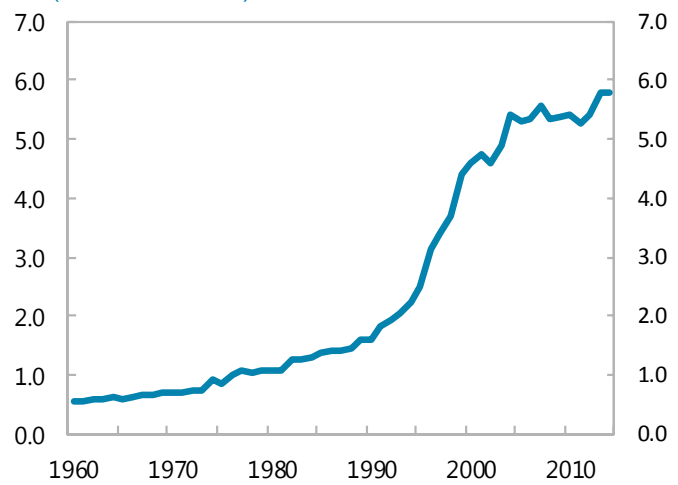

... and half of FDI inflows..

Mining Foreign Direct Investment *

(In percent of FDI inflows in Chile)

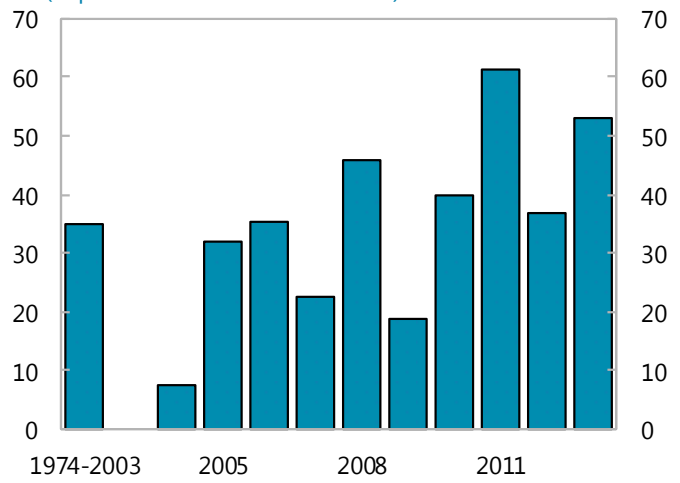

Driven by rising prices, the share of copper production in nominal GDP has increased during 2003-07...

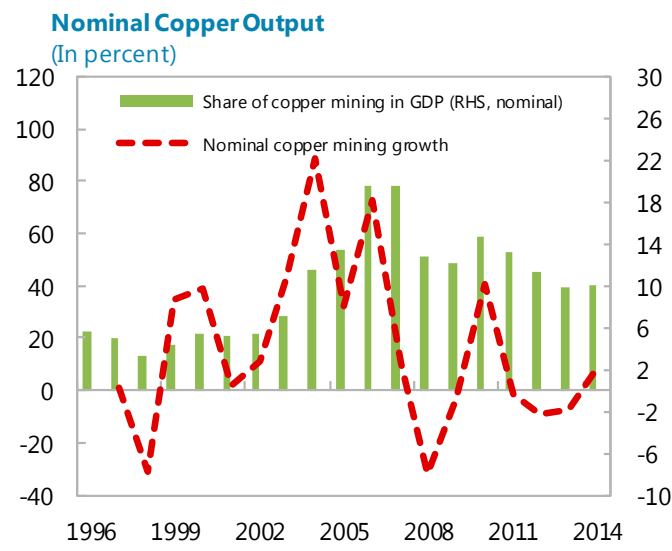

Copper accounts for half of goods exports...

\section{Copper Exports}

(In percent of total exports of goods, unless otherwise stated)

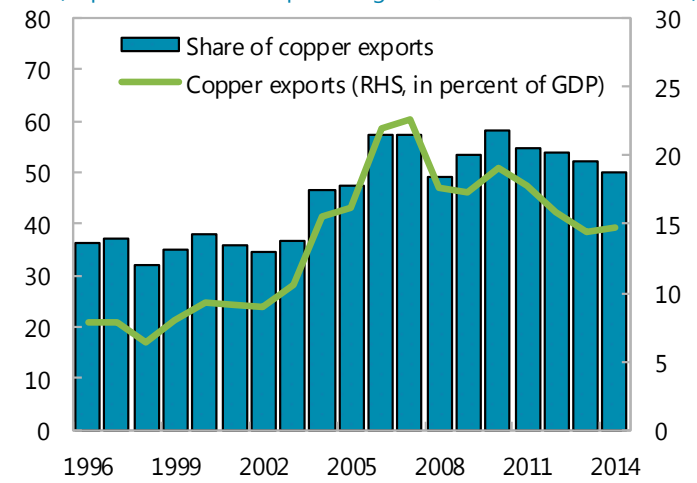

...but only 3 percent of employment, as the sector is very capital-intensive.

Mining Employment

(In percent of total employment, period average)

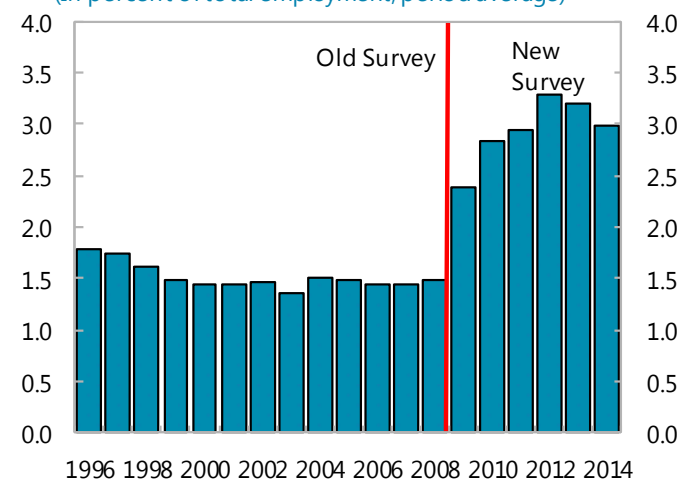

Source: Chilean Copper Commission and Central Bank of Chile.

* Note: FDI Under Decree-Law 600. 
Figure A2. Macroeconomic Effects of Copper Prices in Chile

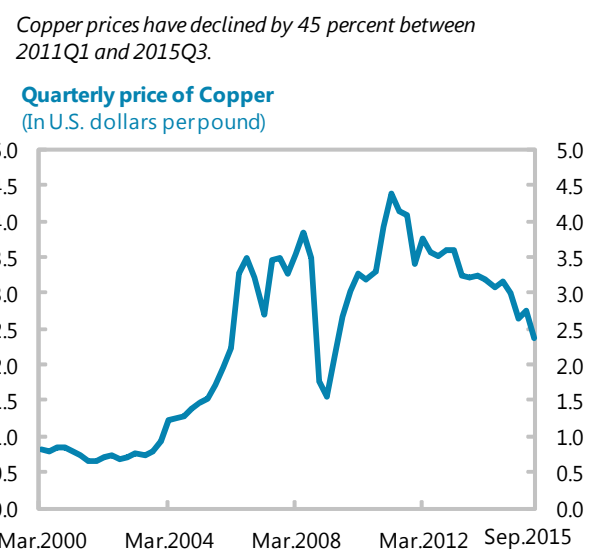

GDP growth and copper price growth display a strong comovement in the short-term.

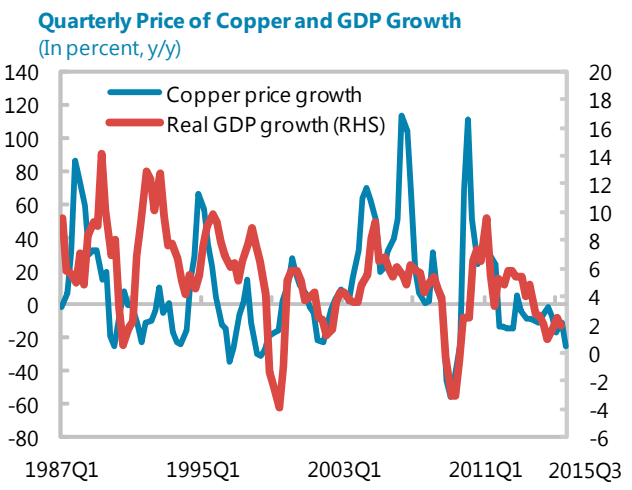

Copper prices are a key driver of the REER...

...and one of the main variables explaining the current account.
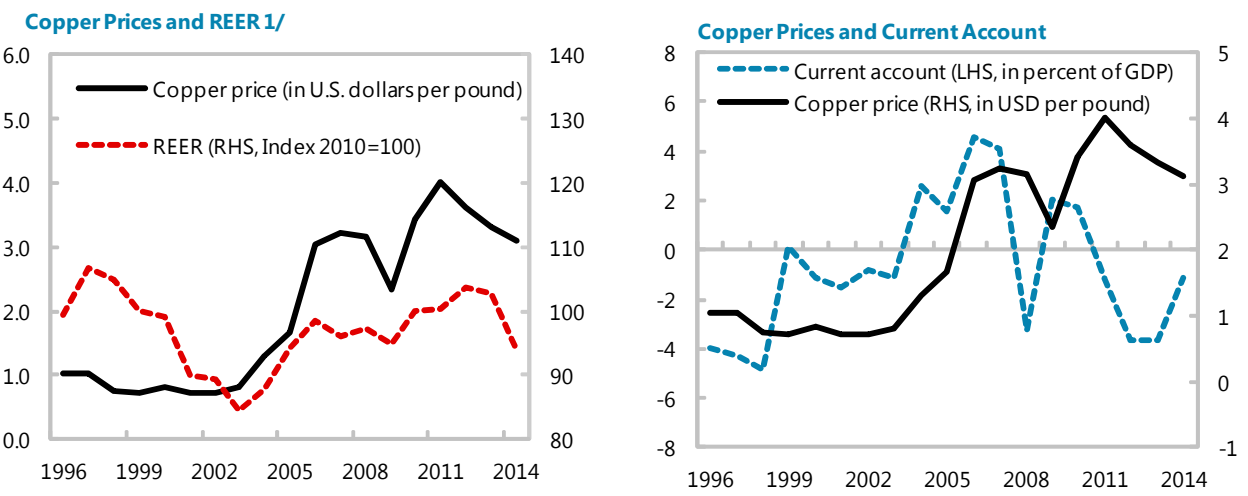

Copper contributes a large share of government revenues...

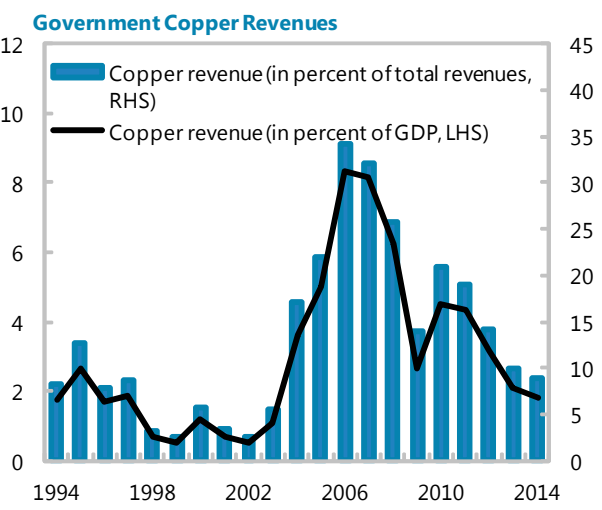

... and, thus, the fiscal position is closely related to the copper price level.

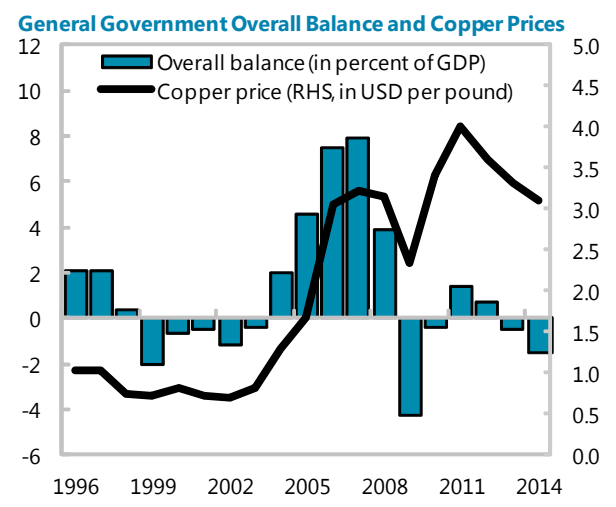

Sources: Central Bank of Chile, Chilean Copper Commission and IMF Staff calculations. $1 /$ REER increase $=$ appreciation . 


\section{REFERENCES}

Aghion P. and P. Howitt, 2009, The Economics of Growth, MIT Press.

Canuto, O., 2014, “The Commodity Super Cycle: Is This Time Different?” Economic Premise, The World Bank.

Collier, P., and B. Goderis, 2012, "Commodity Prices and Growth: An Empirical Investigation,” European Economic Review, 56 pp1241-1260.

CORFO, 2014, "Boletin Trimestral Evolucion de la PTF en Chile 4to Trimestre 2013,“ Universidad Adolfo Ibanez.

Erten, B., and J. A. Ocampo, 2012, "Super-cycles of commodity prices since the midnineteenth century,” DESA Working Paper No. 110ST/ESA/2012/DWP/110.

De Gregorio, J., 2009, "Economic Growth in Chile and Copper," speech given at the Central Bank of Chile in September 2009 available at www.bis.org/review/r090915d.pdf

Fornero, J., M. Kirchner, and A. Yany, 2015, "Terms of Trade Shocks and Investment in Commodity-Exporting Economies," in: Commodity Prices and Macroeconomic Policy, R. Caputo, R. Chang, and D. Saravia (eds.), vol. 21 of Central Banking, Analysis, and Economic Policies, Central Bank of Chile, forthcoming.

Frankel, J. A., 1986, "Expectations and Commodity Price Dynamics: The Overshooting Model," American Journal of Agricultural Economics, Vol. 68, No. 2 (May, 1986), pp. 344-348.

Frankel, J. A., 2011, “A Solution to Fiscal Procyclicality: The Structural Budget Institutions Pioneered by Chile,” NBER Working Paper 16945.

Jacks, D. S., 2013, "From Boom to Bust: A Typology of Real Commodity Prices in the Long Run," NBER Working Paper 18874.

International Monetary Fund, 2014, “2014 Article IV Consultation - Staff Report,” IMF Country Report No. 14/218.

International Monetary Fund, 2015a, “2015 Article IV Consultation - Staff Report,” IMF Country Report No. 15/227.

International Monetary Fund, 2015b, "Northern Spring, Southern Chills," Western Hemisphere Regional Economic Outlook.

Micco, A., and A. Repetto, 2012, "Productivity, Misallocation and the Labor Market," Working Paper 06/2012, Universidad Adolfo Ibáñez, Escuela de Gobierno. 
OECD, 2013, OECD Economic Surveys: Chile 2013, OECD Publishing.

Romer, P., 1986, “Increasing Returns and Long Run Growth,” Journal of Political Economy, 94, 1002-37.

Schwellnus, C., 2010, "Chile: Boosting Productivity Growth by Strengthening Competition, Entrepreneurship and Innovation," OECD Economics Department Working Papers No. 785, OECD Publishing.

Spilimbergo, A., 1999, “Copper and the Chilean Economy 1960-98," IMF WP/99/57.

Van der Ploeg, F., 2011, “Natural Resources: Curse or Blessing?” Journal of Economic Literature, 49:2, 366-420. 